\title{
Phlebotomines (Diptera, Psychodidae) in caves of the Serra da Bodoquena, Mato Grosso do Sul State, Brazil
}

\author{
Eunice A. B. Galati ${ }^{1}$ \\ Vânia L. B. Nunes ${ }^{2}$ \\ Paulo Cesar Boggiani ${ }^{3}$ \\ Maria Elizabeth C. Dorval ${ }^{4}$ \\ Geucira Cristaldo 4 \\ Hilda C. da Rocha ${ }^{4}$ \\ Elisa T. Oshiro ${ }^{4}$ \\ Rute M. Gonçalves-de-Andrade ${ }^{5}$ \\ Guelisa Naufel ${ }^{1}$
}

\begin{abstract}
The present paper deals with the phlebotomine species captured during the period from January 1998 to June 2000 in 12 caves located in the Serra da Bodoquena, situated in the south central region of Mato Grosso do Sul State, Brazil. Three of the caves are situated further north (in Bodoquena county), seven in the central area (Bonito county) and two in the south (Jardim county). These last two caves and three of those in Bonito are located at the west side of the ridge. Eighteen species of phlebotomines were captured within the caves: Brumptomyia avellari (Costa Lima, 1932), Brumptomyia brumpti (Larrousse, 1920), Brumptomyia cunhai (Mangabeira, 1942), Brumptomyia galindoi (Fairchild \& Hertig, 1947), Evandromyia corumbaensis (Galati, Nunes, Oshiro \& Rego, 1989), Lutzomyia almerioi Galati \& Nunes, 1999, Lutzomyia longipalpis (Lutz \& Neiva, 1912), Martinsmyia oliveirai (Martins, Falcão \& Silva, 1970), Micropygomyia acanthopharynx (Martins, Falcão \& Silva, 1962), Micropygomyia peresi (Mangabeira, 1942), Micropygomyia quinquefer (Dyar, 1929), Nyssomyia whitmani (Antunes \& Coutinho, 1939), Psathyromyia campograndensis (Oliveira, Andrade-Filho, Falcão \& Brazil, 2001), Psathyromyia punctigeniculata (Floch \& Abonnenc, 1944), Psathyromyia shannoni (Dyar, 1929), Pintomyia kuscheli (Le Pont, Martinez, Torrez-Espejo \& Dujardin, 1998), Sciopemyia sordellii (Shannon \& Del Ponte, 1927) and Sciopemyia sp. A total of 29,599 phlebotomine sandflies was obtained. Lutzomyia almerioi was absolutely predominant (91.5\%) over the other species on both sides of the Bodoquena ridge, with the exception of the southern caves in which it was absent. It presents summer predominance, with nocturnal and diurnal activities. The species breeds in the caves and was captured during daytime both in the dark area and in the mouth of the caves. Martinsmyia oliveirai, the second most frequent sandfly, also presents a summer peak and only predominated over the other species in one cave, in which there were human residues.0
\end{abstract}

KeYwords. Caves; Diptera; ecology; Phlebotominae; Serra da Bodoquena.

\section{INTRODUCTION}

The growing tourism involving search for natural attractions, as cave exploration, demands a better knowledge of the threats to health that people may face. The visits to caves and other ecosystems in karstic environments of great scenic beauty and pleasure areas have transformed the Serra da Bodoquena, in the State of Mato Grosso do Sul, Brazil, into an important tourist centre. Before 1984 tourism was restricted to local visitors, but the number of tourists coming from other parts of the country and also from abroad increased gradually up to1990, and thence faster (BogGiani 2001).

\footnotetext{
1. Departamento de Epidemiologia, Faculdade de Saúde Pública, Universidade de São Paulo. Av. Dr. Arnaldo 715, 01246-904 São Paulo-SP, Brazil. E-mail: egalati@usp.br

2. Centro de Ciências Biológicas, Agrárias e da Saúde, Universidade para o Desenvolvimento do Estado e da Região do Pantanal. Campo Grande-MS, Brazil. E-mail: vlbnunes@terra.com.br

3. Universidade Federal de Mato Grosso do Sul. Campo Grande-MS, Brazil.

4. Departamento de Patologia, Centro de Ciências Biológicas e da Saúde, Universidade Federal de Mato Grosso do Sul. Campo Grande-MS, Brazil.

5. Laboratório de Imunoquímica, Instituto Butantan. São Paulo-SP, Brazil.
} 
Among the insects that live in or frequent caves and their adjacent environments, the phlebotomines call for special attention not only because several species are vectors of arbovirus diseases, bartonellosis and leishmaniases (ForATtinI 1973; Young \& Duncan 1994; Cipa Group 1999) but also because they are bothersome to man, principally due to their painful bite, frequently causing allergic reactions.

The phlebotomines are distributed throughout the world and there are now about 470 known species in the Americas. These species, though more frequently associated with forests, are also found in areas with other types of vegetation cover and in urban environments. Their immature forms develop in moist soil, protected from the direct incidence of the light and rich in organic substances, found among exposed roots, under fallen leaves and stones, in fissures in rocks, in animal dens and in the anthropic environments, in domestic animal shelters and other ecotopes where appropriate conditions exist (FoRATTINI 1973). The resting sites of adults may be the same as those used for breeding, or tree trunks, living or fallen leaves or holes in trees. The individuals, male or female, have no tendency to wander far from their breeding or resting sites; although they may be captured as far as $1 \mathrm{~km}$ from the point at which they were set free, the majority are captured within less than $250 \mathrm{~m}$ of that point (MORRISON et al. 1993). Individuals of both sexes need sugars as energy source and only the females are considered haematophagous, biting a large sort of vertebrates including mammals, birds and cold blooded animals (COLMENARES et al. 1995; MORRISON et al. 1993). Although their haematophagic activities be essentially nocturnal they also bite during the daytime (Young \& DuNCAN 1994).

Caves, being natural cavities, are commonly found in calcareous areas, whose composition favours the dissolution of the rocks by acid water. Streams of water may pass through them and they thus undergo natural enlargement. Communication with the external environment may occur when the water disappears underground, in sinkholes, or when it reappears as springs, or through the openings caused by caving-in.

As cave ecosystem is relatively more isolated than other ecosystems, with specific and constant physical environments, its fauna and flora present peculiar aspects. The cave environment is characterized by small daily variation of temperature, with the temperature close to the external annual mean; the relative humidity tends to be between $95 \%$ and $100 \%$, the air currents, even strong winds, may occur at great distances from entrances provoked by a chimney effect and by changes in barometric pressure. Three zones may be differentiated: a twilight zone near the entrance, a middle zone of complete darkness and variable temperature, and one of complete darkness and constant temperature in the deepest recesses. The cave soil may present food of a variety of origins, such as animal droppings, vegetal debris, remains of arthropods and other animals found in aqueous solutions and moist or dry soil. The floor material consists of fragmented sedimentary rocks and sand, silt and clay, and also of fallen slabs of rock from the cave ceiling (Poulson \& White 1969).

In accordance with the level of the dependence of animals on the caves, they are classically classified as: troglobites living exclusively inside the caves; troglophiles - may live in the caves but are not strictly confined to them, and trogloxenes - animals that visit the caves, which may be either regular trogloxenes or occasional trogloxenes (VANDEL 1964). So, the troglophiles are cave-dwelling animals which may live and reproduce either in caves or in the external milieu (DESSEN et al. 1980). In tropical lowlands, troglophiles occur in a great variety of species with large populations, while the troglobite species are very few (Poulson \&WHITE 1969).

Records of phlebotomines in the caves of Serra da Bodoquena (GNASPINI-NETTO et al. 1994) and the growing of tourism, involving visits to these caves, led us to undertake studies on faunistic composition and behavior of phlebotomines, as well as to identify the relationships among the species of various environments and the human population. Several points in the Serra da Bodoquena, in both natural and anthropic environments, were sampled and followed up between January 1998 and June 2000. The present work concerns phlebotomine sandflies captured in 12 caves, having as its objectives the study of the diversity and relative abundance of the species as well as the seasonal and monthly distribution of the most frequent species.

\section{MATERIALAND METHODS}

Area studied. The Serra da Bodoquena is situated in the south-central part of the Mato Grosso do Sul State, extending in a N-S direction for $c a .200 \mathrm{~km}$ and from E-W for about $60 \mathrm{~km}$. This geomorphological unit is delimited to the north and west by the depression of the Paraguay river (Pantanal plain), to the east by the Miranda river basin, and to the south by the Apa river basin, constituting the watershed between these three basins (Fig. 1). It is a plateau with an asymmetrical profile having a scarp at the western side and a gentle slope with calcareous residual mountains at the eastern side. Its altitude varies from 400 to $650 \mathrm{~m}$ (BogGiani \& CoImBra 1995).

The caves of the Serra da Bodoquena present the characteristic standard forms of more highly evolved caves, in which large inkasion rooms prevail (KHOLER et al. 1998).

The layers of carbonate rocks in the area in which the caves were formed are folded in the eastern side of the plateau. In the western side, these layers lie horizontally or present open folds. This geological structure implies the existence of two morphologic cave patterns. Those in the east present halls with areas of hundreds of square metres and large openings to the surface, which permit the entrance of light, with the floors of the caves generally following the bends in the layers. Those in the west side tend to appear as underground conduits with relatively greater development than those in the east.

The climate of the region is basically tropical under the influence of polar advections during the winter (June September), when the environment is drier. The mean annual temperature is $22^{\circ} \mathrm{C}$ and average rainfall is $1,450 \mathrm{~mm} /$ year (DNP, 
1992). In the winter the rainfall is less and varies from $30 \mathrm{~mm}$ to $60 \mathrm{~mm} / \mathrm{month}$. From October 1999 to September 2000 the temperature varied from $2.3{ }^{\circ} \mathrm{C}$ to $40.6^{\circ} \mathrm{C}$ and the relative humidity from $17.4 \%$ to $99.9 \%$. The vegetation varies according to the relief and soil type. The level areas of the plateau with red-yellow and dark-red latosols are covered by the savannah vegetation (cerrado) with its variations. Where carbonate rocks outcrop, the soil is shallower and the vegetation is seasonal semideciduous submountainous forest (FurTAdo et al. 1982; Veloso et al. 1991).

\section{Caves studied}

A. Bodoquena county. Three caves were sampled:

Estreito da Serra cave (7739 $967 \mathrm{mN}$ - $530120 \mathrm{mEUTM})$. It is located in a well preserved seasonal semideciduous submountainous forest, at Morro Vermelho farm $\left(20^{\circ} 26^{\prime} \mathrm{S} 56^{\circ}\right.$ $43^{\prime} \mathrm{W}$ ), to the north-east of Bodoquena city, above $250 \mathrm{~m}$ a. s. 1. This cave is the biggest in the region and is basically formed by a single hall with $\mathrm{ca}$. $30^{\circ}$ of inclination. In plan, the cave presents a horseshoe form, with ample penetration of light.

Três Morrinhos cave (77 29300 mN - 531630 mE-UTM). It is situated in a pasture, $3 \mathrm{~km}$ to the north-east of Bodoquena city. Its development is of $c a .65 \mathrm{~m}$, with two main galleries: one, in the form of a bottle-neck, situated in an E-W direction from the entrance, and the other, in a N-S direction, in its interior. The cave is little ornamented, presents a few partially broken stalactites and is a dry cavity without marked water fluxes. In its entrance throat there are accumulated trunks and leaves.

Camargo Corrêa Industrial (C.C.I.) cave $(7727060 \mathrm{mN}-5$ $33320 \mathrm{mE}$ - UTM). It is situated at the side of the Camargo Corrêa Industrial residences, in a mount consisting of fragmented rocks, covered with seasonal semideciduous submountainous forest, in the urban area of Bodoquena city. This cavity is formed by a throat of inclined ground, 1-2 m wide and with a total drop in level of $c a .15 \mathrm{~m}$. The open part of the throat is $1 \mathrm{~m}$ wide, $9 \mathrm{~m}$ long and presents a $3 \mathrm{~m}$ drop in level, with vertical walls in a N15E direction. A dark zone can be reached by descending the inclined ground where some stalactites and accumulated garbage occur in the funnelled bottom among rock blocks.

B. Bonito county. Seven caves, distributed in three areas, were investigated:

Pitangueiras cave (7692227 mN - $543161 \mathrm{mEUTM})$. It is located in a farm of the same name, half way from Bodoquena to Bonito. Its entrance is situated in a narrow strip of forested savannah ("cerradão") relatively well preserved, delimited by pasture and $c a .200 \mathrm{~m}$ from a residential area. It is a labyrinthine cave, with inter-linked galleries constituted by vertical canyons. Its principal entrance is an inkasion room and skylights constitute four secondary entrances (SALLUM-FILHO 1996) that permit good circulation of fresh air. It also presents various galleries in total darkness. In general, it is little ornamented and has conduits of dissolution that follow the fracture system of the rock massif. It presents no continuous water flux, remaining dry during the winter, though it is possible to observe a dry river-bed in its interior.

Anhumas Nucleus: São Miguel cave (76 65842 mN - 543 759 mE UTM), also called Carneiro Cave. It is located in the São Miguel farm in the middle of forested savannah, modified for the construction of a suspended foot-bridge and restaurant during the period in which this study was undertaken. Its interior was also modified by artificial illumination. It was opened to tourists at the end of 1999. It has two large entrances: one to the south, that due to facility of access is considered the main one $(20 \mathrm{mx} 10 \mathrm{~m})$ and the other to the NW (30 $\mathrm{mx} 4 \mathrm{~m})$. There is also a small third entrance near this latter of $c a .1 \mathrm{~m}$ in diameter. Because of its two large entrances, the cave is almost completely illuminated, with isolated dark spots.

Lago Azul cave (76 $61789 \mathrm{mN}$ - $542515 \mathrm{mE}$ UTM) is ca. 13 $\mathrm{km}$ from the São Miguel cave. The surrounding vegetation is an ecotone between forested savannah and seasonal deciduous low-lying forest. It has two main compartments: the lake hall and the Coral gallery, sub-compartments and sets of galleries. The cave entrance is located at the SE extremity of the Lake hall and due to its large size, it is illuminated almost throughout its length, but even so there are some rooms in complete darkness. Despite its large entrance and consequent external influence, the environmental parameters, temperature and relative humidity do not vary greatly (LiNO et al. 1984). The cave is completely fenced off, though small mammals still have access to its interior.

Nossa Senhora Aparecida (N. Sra. Aparecida) cave (76 67 $671 \mathrm{mN}-544257 \mathrm{mE}$ UTM) is located $2 \mathrm{~km}$ from the Lago Azul cave, in an area of the same vegetation type. It is formed by an ample hall, the largest dimension of which is $100 \mathrm{~m}$ in a NE direction. It presents an entrance of elliptical form, $20 \mathrm{~m}$ wide with a height varying from 1.0 to $3.0 \mathrm{~m}$ and situated under a rocky wall. Inside the cave the height varies from $1.5 \mathrm{~m}$, close to the entrance, to $32 \mathrm{~m}$ at the dome located at the NE end of the hall on an argillaceous plain. The cave is well illuminated throughout in almost all of its extension but some rooms in totally darkness (LiNo et al. 1984). It is completely fenced off, as is the Lago Azul Cave.

Guaicurus Settlement Nucleus is situated in the central part of the western side of the Serra da Bodoquena, near the limits of the Kadwéus Indian Reserve, located in Porto Murtinho county. The Guaicurus Settlement is in a very poor dry area. It consists of small home-farms, with calcareous soils and with few arable areas. The Três Coxilhas farm, despite of not belonging to the settlement, it was included in this nucleus.

Gaúcho's cave (76 $92 \mathrm{mN}-0516 \mathrm{mE}$ UTM), as it is known in the region, is situated in the north of the settlement area, in the Três Coxilhas farm, in an area covered with relatively well preserved forested savannah. The cave consists of a hall $60 \mathrm{~m}$ long, with width varying from 10 to $20 \mathrm{~m}$. Its entrance is approximately circular, of $5 \mathrm{~m}$ diameter, which permits illumination of large part of the cave. It has no continuous water flow, but presenting rich ornamentation.

Cezário's cave ( $7692 \mathrm{nN}$ - $516 \mathrm{mE}$ UTM). It is a small cave 


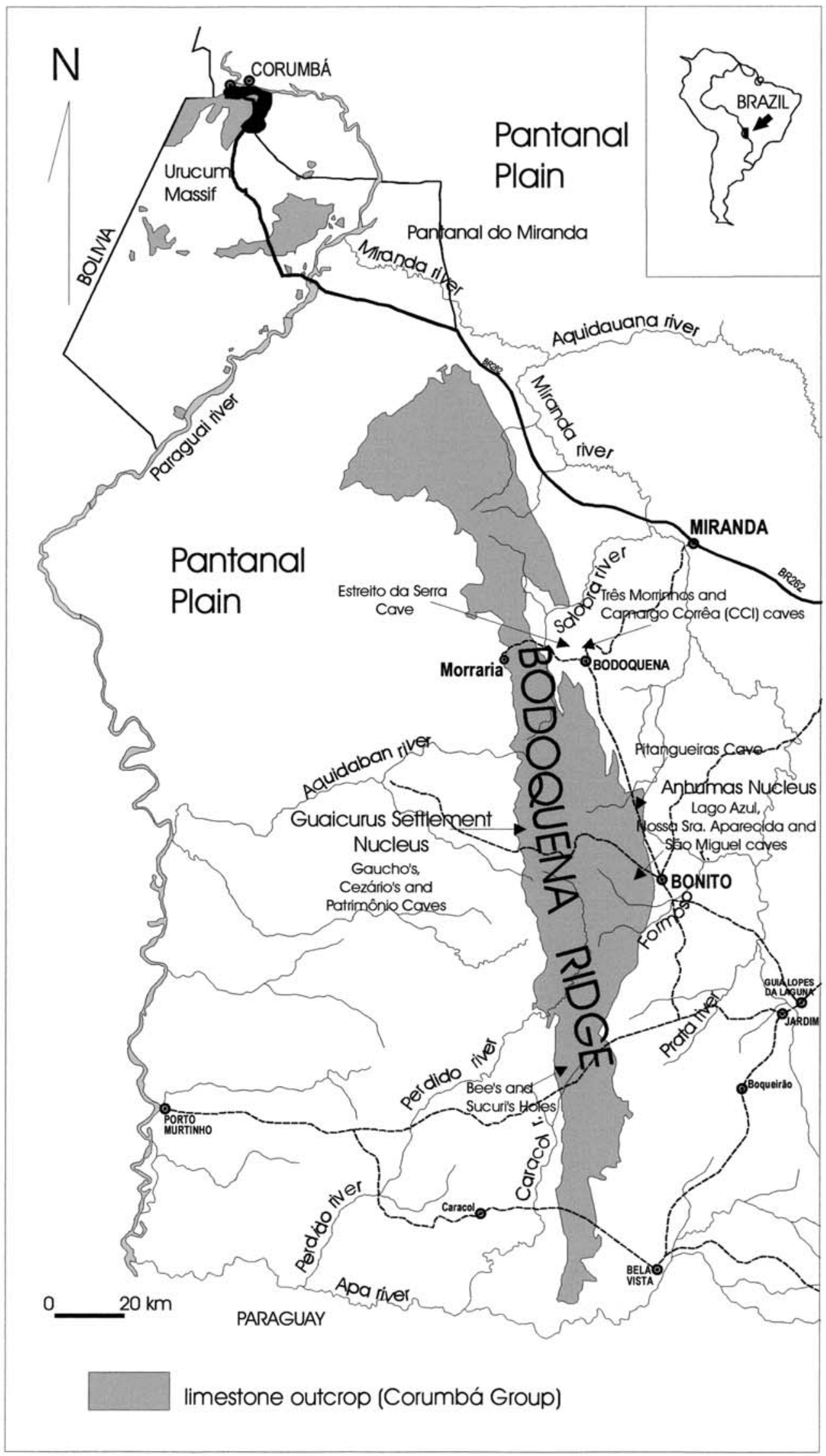

Fig. 1. Map of the Serra da Bodoquena. Arrows show the localization of the caves studied. 
located $1 \mathrm{~km}$ from the Gaúcho's cave. It is situated in a mountain originally covered by seasonal semideciduous submountainous forest, now considerably modified, in the land belonging to a private house. Its entrance is less than one meter in diameter which gives access to a hall of greater length than width, with a height of $1.0-1.5 \mathrm{~m}$. No continuous water flow was observed.

Patrimônio cave ( $7692 \mathrm{mN}-516 \mathrm{mE}$ UTM $)$. It is situated within a mountain in front of the central village of the settlement, $20 \mathrm{~m}$ above the foot of the mountain, on a slope covered by primitive vegetation represented by seasonal semideciduous submountainous forest of which some few trees have been preserved. Its entrance has a height of $1 \mathrm{~m}$ and gives access to a small room, the height of which is smaller than that of the entrance. The cave has little ornamentation and was dry when visited.

C. Jardim county. Two cavities located in the Figueira farm were sampled. Access to this farm is by the road that links the towns of Jardim and Porto Murtinho.

Buraco das Abelhas ( $7620 \mathrm{mN}-530 \mathrm{mE}$ UTM). This cavity is situated $6 \mathrm{~km}$ from the main farmhouse and lies in north-westernly direction in an area covered by forested savannah. It is a small elliptical opening, $1 \mathrm{~m}$ high and $5 \mathrm{~m}$ wide, with an underground river conduit. The opening received this name because of the great concentration of bees (Apis mellifera) in the entrance.

Buraco da Sucuri (76 20 mN - $530 \mathrm{mE}$ UTM) is a cavity situated in an area covered by forested savannah, $1 \mathrm{~km}$ from the main farmhouse. It is a doline, $c a .30 \mathrm{~m}$ long and 3-5 m deep, with large blocks of rock in its interior. Normally it is dry, but in rainy periods a temporary stream may occur.

\section{Methodology}

Two strategies for the capture of adults were adopted: i) fortnightly samples were obtained by local inhabitants; ii) captures were carried out by team-members, once in each season of the year in Bodoquena county and in the three areas of Bonito county.

The captures undertaken by local inhabitants were made with automatic light traps (NATAL et al. 1991) containing in their bottom a small piece of filter paper with a drop of the insecticide Dichlorvos. In these traps the collection chamber is internal to the body of the trap, anterior to the fan.

With the exception of the N. Sra. Aparecida cave, in which two traps were installed at its entrance, only one trap was installed at the entrance of the others or at the main entrance when there were two or more, during the period between 6:00 p.m. and 6:00 a. m. The capture intervals were not the same for all the caves: Três Morrinhos and C.C.I. - August 1998 to December 1999, Pitangueiras - January 1998 to March 2000, São Miguel - January 1998 to December 1999, Lago Azul January 1998 to June 2000, N. Sra. Aparecida - January to June 2000, Gaúcho and Cezário - January 1998 to December 1999, Patrimônio - June 1998 to December 1999, Buraco das Abelhas and Buraco da Sucuri - February 1999 to January 2000.
Besides these captures, three others, in February, May and July 1998, were undertaken in the Estreito da Serra cave in Bodoquena county.

Diurnal captures were also undertaken from 8:00 a. m. to 5:00 p. $\mathrm{m}$ in a dark zone of the Gaucho's cave with the same nocturnal periodicity.

The insects captured by local inhabitants were stored in small boxes with naphtha and sent to the Phlebotomine Laboratory at the Faculdade de Saúde Pública, Universidade de São Paulo, for identification.

In the three areas of Bonito county captures were carried out by the team-members without any predetermined periodicity and the females kept alive for breeding or dissection to observe any natural infection by flagellates. The automatic light traps were modified for this purpose, the collection chamber being connected to the body of the trap by sleeves made of cotton cloth, $20 \mathrm{~cm}$ long by $10 \mathrm{~cm}$ in diameter. Ten diurnal captures were made with these traps in the Pitangueiras cave alone, each with 6 hours of exposure between 8:00 a.m. and 5:00 p.m., between April 1998 and January 2000 . The females captured were treated as those above but the males were killed and maintained in small boxes with naphtha, for identification. In four of these captures, in July, August, September and December of 1999, the traps were exposed simultaneously within a dark zone of the cave and in the twilight zone of the cave's entrance.

For the purpose of collecting sandflies in their natural resting sites, for dissection and to observe natural infection by flagellates, captures with aspirator (6 volts) were made during the afternoon on the walls and in fissures of some caves. A total of 24 hours of aspiration was undertaken, as follows: C.C.I. (3 h), Pitangueiras (2 h), Lago Azul (3 h) São Miguel (8 h) and Cezário (8h).

For the investigation of natural infection by flagellates, the females were freed in a small cage and recaptured in flasks in which they were immobilised with ethyl ether. After this they were transferred to a slide containing a drop of saline solution, in which, under a stereomicroscope, the posterior portion of the abdomen was submitted to a traction to expose the digestive tract, which remained united to the genital part. Thus the rest of the female body was withdrawn from the drop and only the digestive tract and genitalia were covered by a cover-glass and examined under a microscope to search for flagellates and identification of the phlebotomine.

The identification of the other specimens of phlebotomines was made after their clarification according to the method given by FoRATTINI (1973) and examination in creosote. Some of these specimens were mounted on slides and later deposited in the collection of Departamento de Epidemiologia, Faculdade de Saúde Pública, Universidade de São Paulo.

Samples of soil were collected to study the sandfly breeding sites in three occasions in the Pitangueiras and Lago Azul caves and once in both the Cezário and Gaúcho caves. The soil was examined under a stereomicroscope and preserved to serve as substrate and food for breeding in the laboratory.

Statistical analyses. The seasonal distribution of the most 
Table I. Average number per automatic light trap of phlebotomines of both sexes captured from 6:00 p. m. to 6:00 a. m., by the species and caves of the Serra da Bodoquena, Mato Grosso do Sul State, Brazil, January 1998 to June 2000.

\begin{tabular}{|c|c|c|c|c|c|c|c|c|c|c|c|c|c|}
\hline \multirow[b]{2}{*}{ umber of traps } & \multicolumn{3}{|c|}{ Bodoquena } & \multirow{2}{*}{$\begin{array}{l}\text { Pitan- } \\
\text { gueiras }\end{array}$} & \multicolumn{3}{|c|}{ Anhumas Nucleus } & \multicolumn{3}{|c|}{ Guaicurus Settlement } & \multicolumn{2}{|c|}{ Jardim } & \multirow[b]{2}{*}{ Total } \\
\hline & $\begin{array}{c}\text { Estrei- } \\
\text { to da } \\
\text { Serra } \\
3\end{array}$ & $\begin{array}{c}\text { Três } \\
\text { Morri- } \\
\text { nhos } \\
33\end{array}$ & C.C.I. & & $\begin{array}{c}\text { São } \\
\text { Miguel } \\
46\end{array}$ & $\begin{array}{c}\text { Lago } \\
\text { Azul } \\
\\
58\end{array}$ & $\begin{array}{c}\text { N. Sra. } \\
\text { Apare- } \\
\text { cida } \\
24\end{array}$ & $\begin{array}{c}\text { Gaú- } \\
\text { cho } \\
47\end{array}$ & $\begin{array}{c}\text { Cezá- } \\
\text { rio } \\
47\end{array}$ & $\begin{array}{c}\text { Patri- } \\
\text { mônio } \\
35\end{array}$ & $\begin{array}{l}\text { Abe- } \\
\text { lhas } \\
24\end{array}$ & Sucuri & \\
\hline B. avellari & - & - & - & - & 0.07 & 0.10 & - & - & - & - & - & - & 0.021 \\
\hline B. brumpti & - & 0.06 & - & - & 0.09 & 0.03 & 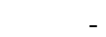 & 0.02 & 0.02 & - & 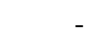 & - & 0.019 \\
\hline B. cunhai & - & - & - & 0.25 & 0.04 & - & - & 0.21 & - & 0.03 & - & - & 0.061 \\
\hline B. galindoi & - & - & - & - & 0.02 & - & - & - & - & - & - & - & 0.002 \\
\hline Brumptomyia sp.* & - & - & - & - & - & 0.05 & 0.04 & - & - & - & - & - & 0.012 \\
\hline E. corumbaensis & 0.67 & 0.33 & 2.52 & 0.35 & 2.35 & 0.24 & 0.33 & 0.04 & 0.72 & 0.80 & - & - & 0.723 \\
\hline L. almerioi & 392.00 & 40.03 & 8.88 & 249.56 & 141.54 & 8.55 & 52.4 & 0.70 & 2.81 & 2.69 & - & - & 57.016 \\
\hline L. longipalpis & 1.67 & 2.00 & 0.06 & 0.62 & 0.33 & 0.09 & 0.63 & - & 1.23 & 0.43 & - & - & 0.500 \\
\hline M. oliveirai & 49.33 & 0.58 & 11.15 & 1.58 & 9.15 & 0.19 & - & - & 1.13 & 0.34 & - & - & 2.615 \\
\hline M. acanthopharynx & - & - & - & 0.10 & - & - & - & - & - & - & - & - & 0.012 \\
\hline M. peresi & 2.67 & 0.67 & 1.15 & 1.54 & 0.44 & 0.02 & 0.08 & - & - & 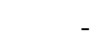 & - & - & 0.401 \\
\hline M. quinquefer & 0.33 & 0.06 & - & 1.65 & 0.09 & 0.02 & - & - & - & 0.03 & - & - & 0.223 \\
\hline N. whitmani & 1.00 & 1.06 & 0.12 & 0.25 & 1.04 & 0.34 & 0.08 & 0.12 & 0.09 & 0.09 & 0.08 & - & 0.333 \\
\hline P. kuscheli & - & - & - & - & - & - & - & - & 0.02 & - & - & - & 0.002 \\
\hline P. campograndensis & - & - & - & - & - & 0.02 & - & - & - & - & - & - & 0.002 \\
\hline P. punctigeniculata & - & 0.03 & 0.03 & - & 0.04 & - & - & - & 0.02 & - & - & - & 0.012 \\
\hline P. shannoni & - & - & 0.30 & - & 0.11 & 0.10 & - & - & 0.15 & - & - & 0.17 & 0.075 \\
\hline S. sordellii & 0.33 & 0.39 & 1.94 & 0.10 & 2.41 & 0.16 & 1.58 & 0.06 & 1.83 & 0.03 & - & - & 0.777 \\
\hline Sciopemyia sp. & - & - & - & 0.02 & - & - & - & - & - & - & - & - & 0.002 \\
\hline Total & 448.00 & 45.21 & 26.15 & 256.00 & 157.70 & 9.91 & 55.17 & 1.15 & 8.02 & 4.43 & 0.08 & 0.17 & 62.808 \\
\hline
\end{tabular}

* Specimens damaged; without possibility of specific identification.

numerous species was obtained by Williams'geometric mean (HADDOw 1960).

For the abundance calculation, data of captures carried out with automatic light traps, fortnightly, between 6:00 p. m. and 6:00 a. m., during the period from August 1998 to December 1999, in eight caves: C.C.I., Três Morrinhos, Gaúcho, Cezário, Patrimônio, Pitangueiras, São Miguel and Lago Azul, were used. The Standardised Index of Species Abundance was calculated according to ROBERTS \& Hsi (1979).

The estimates of diversity were obtained using Margalef's Index (SERVICE 1993) and the difference between the number of insects captured in dark and twilight zones was assessed by Mann-Whitney's Test (SIEGEL 1975).

The species nomenclature adopted is that of GALATI (1995).

\section{RESULTSANDDISCUSSION}

Eighteen sandfly species belonging to nine genera and four subtribes of Phlebotomini were captured in the caves sampled at the Serra da Bodoquena: Brumptomyiina: Brumptomyia avellari (Costa Lima, 1932), Brumptomyia brumpti (Larrousse, 1920), Brumptomyia cunhai (Mangabeira, 1942), Brumptomyia galindoi (Fairchild \& Hertig, 1947); Lutzomyiina: Evandromyia corumbaensis (Galati, Nunes, Oshiro \& Rego, 1989), Lutzomyia almerioi Galati \& Nunes, 1999, Lutzomyia longipalpis (Lutz \& Neiva, 1912), Pintomyia kuscheli (Le Pont, Martinez, TorrezEspejo \& Dujardin, 1998), Sciopemyia sordellii (Shannon \& Del Ponte, 1927), Sciopemyia sp; Psychodopygina: Martinsmyia oliveirai (Martins, Silva \& Falcão, 1970), Nyssomyia whitmani
(Antunes \& Coutinho, 1939), Psathyromyia campograndensis (Oliveira, Andrade-Filho, Falcão \& Brazil, 2001), Psathyromyia punctigeniculata (Floch \& Abonnenc, 1944), Psathyromyia shannoni (Dyar, 1929); Sergentomyiina: Micropygomyia acanthopharynx (Martins, Falcão \& Silva, 1962), Micropygomyia peresi (Mangabeira, 1942) and Micropygomyia quinquefer (Dyar, 1929).

Of the phlebotomines captured at the Serra da Bodoquena, ten species, B. avellari, B. brumpti, B. galindoi, E. corumbaensis, L. almerioi, L. longipalpis, M. oliveirai, $M$. acanthopharynx, M. peresi and P. shannoni are among the about 60 species cited as occupying caves or rocky environments (Williams 1976; Lugo et al. 1991; Young \& Duncan 1994; Galati et al. 1997; Galati \& NunEs 1999; Cipa Group 1999).

Of the four subtribes of Phlebotomini among which the eighteen species captured in caves of the Serra da Bodoquena are distributed, Lutzomyiina contributed with $94 \%$ of the specimens, Psychodopygina with 4.8\%, Sergentomyiina with $1.0 \%$ and Brumptomyiina with $0.2 \%$ (Table I). This great predominance of Lutzomyiina was largely due to L. almerioi, which represented $96.6 \%$ of the subtribe. This pattern of dominance was also observed by WiLliams (1976) for limestone caves in Belize, Central America, where Lutzomyiina accounted for $94.7 \%$ of the specimens captured, and Dampfomyia disneyi (Williams, 1987) [=Lutzomyia beltrani (Vargas \& Díaz Nájera) Belize form] represented $90.6 \%$ of this subtribe. In the second most numerous group, Psychodopygina, the species $M$. oliveirai accounted for $86.1 \%$. 
Even excluding these two species, Lutzomyiina still predominated (63.1\%), followed by Sergentomyiina (20.0\%), Psychodopygina (13.3\%) and Brumptomyiina (2.0\%). This gradient of dominance has also been observed in a cave (Gruta da Santa) in Corumbá county situated in the Pantanal region (GALATI et al. 1997), which borders the Serra da Bodoquena, with the values of $84.4 \%, 14.8 \%, 0.5 \%$ and $0.3 \%$, respectively.

Of the eight species captured in that cave in the Pantanal, five also occur at the Serra da Bodoquena: B. brumpti, E. corumbaensis, M. oliveirai, M. peresi and S. sordellii. The other three, Lutzomyia cruzi (Mangabeira, 1938) and Lutzomyia forattinii Galati, Rego, Nunes \& Teruya, 1985, present affinity, respectively, with $L$. longipalpis and $L$. almerioi found at the Bodoquena and the third, Evandromyia sallesi (Galvão \& Coutinho, 1939), is close to E. corumbaensis, present in both regions. However, the predominance of the species in the Pantanal cave was very different from that at the Serra da Bodoquena, i. e, in the former E. corumbaensis predominated, followed by $S$. sordellii, L. forattinii and M. peresi, with sporadic occurrence of $M$. oliveirai and B. brumpti.

Though the Pantanal and Serra da Bodoquena are adjacent areas, the probable vectors of visceral leishmaniasis in Corumbá, L. cruzi (GALATI et al. 1997; SANTOS et al. 1998) and L. forattinii (Galati et. al. 1997), were not captured at the Serra da Bodoquena. Perhaps this pattern of geographical distribution is to be explained by the difference in altitude between the two areas, with the average temperature in Corumbá being some $4{ }^{\circ} \mathrm{C}$ above that at the Serra da Bodoquena. Also by the higher relative humidity in the Gruta da Santa than at the entrance of the caves at the Bodoquena, since the former is situated on the banks of a lake (Lagoa do Tamengo) close to the Paraguay river and the latter in forested areas or pasture, having consequently, much drier environments.

A total of 29,599 phlebotomine sandflies were captured in the caves of the Serra da Bodoquena using automatic light traps (Tables I-V) or aspirators. Of this total, 26,757 specimens (90.4\%) were captured by local inhabitants; the average capture of which by species and cave is presented in Table I. Only N. whitmani and P. shannoni were captured in the cavities situated further to the south at the Serra da Bodoquena. The first species presented the widest distribution on the range. Five species, B. galindoi, M. acanthopharynx, P. kuscheli, $P$. campograndensis and Sciopemyia sp., were each captured in only one of the caves. L. almerioi whose type-locality is the Lago Azul cave (GALATI \& NUNES 1999) accounted for 91.0\%. Apart from the caves in Jardim county, this species predominated in all the others, except in the C.C.I., where it was exceeded by $M$. oliveirai (Table I). Hence its abundance index close to 1.0 (Table VI).

Some aspects that distinguish the C.C.I. cave from the others concern its localization in an urban area and the presence of anthropic residues, which generally attract rats; the presence of which latter was observed while uninterrupted 24-hour captures were being carried out in the forest close to the cave (paper in preparation). So, the predominance of $M$. oliveirai, a species whose feeding habits are unknown, is perhaps to be associated with these rodents. Another aspect that reinforces this point of view is that it belongs to a taxon

Table II. Frequency by sex of the species captured with automatic light trap, 6:00 p. m. to 6:00 a. m. and by sampled caves in the Serra da Bodoquena, Mato Grosso do Sul State, Brazil, January 1998 to June 2000.

\begin{tabular}{|c|c|c|c|c|c|c|c|c|c|c|c|c|c|c|c|c|c|c|c|c|c|c|c|c|c|c|}
\hline \multirow[b]{3}{*}{ Species } & \multicolumn{6}{|c|}{ Bodoquena } & \multirow{2}{*}{\multicolumn{2}{|c|}{\begin{tabular}{|c|} 
Pitan- \\
gueiras
\end{tabular}}} & \multicolumn{6}{|c|}{ Anhumas } & \multicolumn{6}{|c|}{ Guaicurus } & \multicolumn{4}{|c|}{ Jardim } & \multirow{2}{*}{\multicolumn{2}{|c|}{ Total }} \\
\hline & \multicolumn{2}{|c|}{$\begin{array}{c}\text { Estrei- } \\
\text { to da } \\
\text { Serra }\end{array}$} & $\begin{array}{r}\mathrm{T}_{1} \\
\mathrm{Mc} \\
\mathrm{nh}\end{array}$ & $\begin{array}{l}\text { tês } \\
\text { rri- } \\
\text { os }\end{array}$ & C.C & C.I. & & & \multicolumn{2}{|c|}{\begin{tabular}{|c|} 
São \\
Miguel
\end{tabular}} & \multicolumn{2}{|c|}{$\begin{array}{l}\text { Lago } \\
\text { Azul }\end{array}$} & \multicolumn{2}{|c|}{$\begin{array}{c}\text { N. Sra. } \\
\text { Apare- } \\
\text { cida }\end{array}$} & \multicolumn{2}{|c|}{$\begin{array}{l}\text { Gaú- } \\
\text { cho }\end{array}$} & \multicolumn{2}{|c|}{$\begin{array}{l}\text { Cezá- } \\
\text { rio }\end{array}$} & \multicolumn{2}{|c|}{$\begin{array}{l}\text { Patri- } \\
\text { mônio }\end{array}$} & \multicolumn{2}{|c|}{$\begin{array}{c}\text { Abe- } \\
\text { lhas }\end{array}$} & \multicolumn{2}{|c|}{ Sucuri } & & \\
\hline & $\mathrm{m}$ & $\mathrm{f}$ & $\mathrm{m}$ & $\mathrm{f}$ & $\mathrm{m}$ & $\mathrm{f}$ & $\mathrm{m}$ & $\mathrm{f}$ & $\mathrm{m}$ & $\mathrm{f}$ & $\mathrm{m}$ & $\mathrm{f}$ & $\mathrm{m}$ & $\mathrm{f}$ & $\mathrm{m}$ & $\mathrm{f}$ & $\mathrm{m}$ & $\mathrm{f}$ & $\mathrm{m}$ & $\mathrm{f}$ & $\mathrm{m}$ & $\mathrm{f}$ & $\mathrm{m}$ & $\mathrm{f}$ & $\mathrm{m}$ & $\mathrm{f}$ \\
\hline B. avellari & - & - & - & - & - & - & - & - & 0.7 & 0.3 & 1.0 & - & - & - & - & - & - & - & & - & - & - & - & & 0.6 & 0.4 \\
\hline$m p t i$ & - & - & - & 1.0 & - & 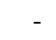 & - & - & 0.5 & 0.5 & 1.0 & & - & - & 1.0 & & - & 1.0 & . & & & 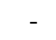 & 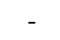 & & 0.6 & 0.4 \\
\hline nhai & - & - & - & . & - & . & 1.0 & - & 0.5 & 0.5 & - & - & . & 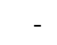 & 0.6 & 0.4 & - & - & 1.0 & & - & - & - & & 0.5 & 0.5 \\
\hline indoi & - & - & - & - & - & . & - & - & 1.0 & - & - & 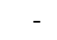 & - & - & - & - & - & - & - & - & - & - & - & - & 1.0 & - \\
\hline tomyi & - & - & - & - & - & - & - & - & - & - & - & 1.0 & - & 1.0 & 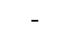 & - & - & - & - & & _. & - & - & & - & 1.0 \\
\hline E. C & - & 1.0 & 0.6 & 0.4 & 0.4 & 0.6 & 0.6 & 0.4 & 0.4 & 0.6 & 0.1 & 0.9 & 0.4 & 0. & - & 1.0 & 0.5 & 0.5 & 0.1 & 0 & - & - & - & & 0.4 & 0.6 \\
\hline L. $c$ & .4 & 0.6 & 0.5 & 0.5 & 0.6 & 0.4 & & 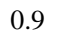 & 0.5 & 0.5 & 0.3 & 0.7 & 0.2 & 0.8 & 0.6 & 0.4 & 0.7 & 0.3 & 0.5 & & & & & & 0.3 & 0.7 \\
\hline alp & 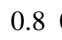 & 0.2 & 0.8 & 0.2 & 0.5 & 0.5 & 0 & & 0.7 & 0.3 & 0.8 & 0.2 & 0.5 & 0.5 & - & - & 0.8 & 0.2 & 0.9 & & & - & & & 0.8 & 0.2 \\
\hline . & 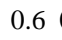 & 0.4 & 0.4 & 0.6 & 0.6 & 0.4 & 0 & c & 0.5 & 0.5 & 0.9 & 0.1 & 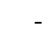 & & 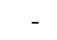 & - & 0.6 & 0.4 & 0.5 & 0. & 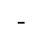 & 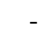 & 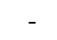 & & 0.6 & 0.4 \\
\hline thoph & - & - & - & - & - & 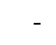 & 0 & & - & - & - & - & . & . & - & & . & 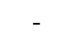 & - & & - & - & - & & 0.6 & 0.4 \\
\hline & & 0.5 & 0.2 & 0.8 & 0.4 & 0.6 & 0 & 0.5 & 0.3 & 0.7 & 1.0 & - & 1.0 & & - & & & & - & & - & - & 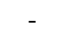 & & 0.4 & 0.6 \\
\hline que & & - & 1.0 & - & - & & 0 & 0.5 & 0.5 & 0.5 & 1.0 & - & 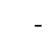 & 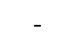 & - & - & - & - & - & 1. & - & - & - & & 0.5 & 0.5 \\
\hline mani & & 1.0 & 0.5 & 0.5 & 0.3 & 0.7 & 0.2 & 0.8 & 0.8 & 0.2 & 0.2 & 0.8 & 1.0 & - & 0.6 & 0.4 & 0.5 & 0.5 & 0.3 & 0.6 & - & .0 & - & & 0.5 & 0.5 \\
\hline P. $k$ & - & - & - & - & - & - & - & - & - & - & - & - & - & - & - & - & 1.0 & - & - & - & - & - & - & - & 1.0 & - \\
\hline$P . c$ & - & - & - & - & - & 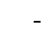 & - & - & - & - & & 1.0 & - & - & - & - & - & - & - & - & - & - & - & & - & 1.0 \\
\hline$P .1$ & - & - & - & 1.0 & - & 1.0 & - & - & 1.0 & - & - & - & 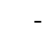 & - & - & - & 1.0 & . & - & - & - & - & - & - & 0.6 & 0.4 \\
\hline oni & $\begin{array}{ll}- & - \\
-1\end{array}$ & - & - & - & 1.0 & - & - & _- & 1.0 & - & 0.3 & & - & - & - & - & 0.4 & 0.6 & - & - & - & - & 1.0 & & 0.8 & 0.2 \\
\hline & 1 & - & 0.5 & 0.5 & 0.3 & 0.7 & 0.4 & 0.6 & 0.4 & 0.6 & 0.3 & 0.7 & 0.4 & 0.6 & 0.3 & 0.6 & 0.5 & 0.5 & - & 1.0 & - & - & - & & 0.4 & 0.6 \\
\hline sclope & 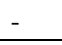 & - & - & - & - & - & - & 1.0 & - & - & - & - & - & - & - & - & - & - & - & 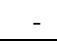 & - & - & - & - & - & 1.0 \\
\hline Total & 0.4 & 0.6 & 0.5 & 0.5 & 0.6 & 0.4 & 0.1 & 0.9 & 0.5 & 0.5 & 0.3 & 0.7 & 0.2 & 0.8 & 0.5 & 0.5 & 0.6 & 0.4 & 0.5 & 0.5 & & 1.0 & 1.0 & & 0.3 & 0.7 \\
\hline
\end{tabular}

* Specimens damaged; without possibility of specific identification . 
Tabel III. Mean capture of both sexes and the female frequencies of L. almerioi in Pitangueiras and São Miguel caves by season of 1998 and 1999.

\begin{tabular}{|c|c|c|c|c|c|c|c|c|}
\hline \multirow{2}{*}{$\begin{array}{r}\text { Cave } \\
\text { Season }\end{array}$} & \multicolumn{4}{|c|}{ Pitangueiras } & \multicolumn{4}{|c|}{ São Miguel } \\
\hline & summer & fall & winter & spring & summer & fall & winter & spring \\
\hline $\begin{array}{l}1998 \\
\text { Mean }\end{array}$ & 1079.8 & 258.7 & 31.3 & 127.5 & 260.3 & 178.8 & 136.0 & 200.7 \\
\hline Female freq. & 0.91 & 0.92 & 0.87 & 0.90 & 0.36 & 0.54 & 0.38 & 0.48 \\
\hline 1999 & & & & & & & & \\
\hline Mean & 329.0 & 40.5 & 18.8 & 71.3 & 245.8 & 149.4 & 17.0 & 1,3 \\
\hline Female freq. & 0.91 & 0.72 & 0.74 & 0.89 & 0.60 & 0.59 & 0.34 & 0.67 \\
\hline Total & 662.7 & 141.2 & 50.2 & 99.4 & 252.1 & 161.7 & 83.5 & 101.0 \\
\hline Female freq. & 0.91 & 0.90 & 0.82 & 0.90 & 0.49 & 0.51 & 0.38 & 0.48 \\
\hline
\end{tabular}

that presents affinity with the Martinsmyia gasparviannai group (GALATI 1995), a species strongly attracted by rodents (FALQUETO et al. 1985).

The low frequencies of L. almerioi in the caves at the western slope of the Serra da Bodoquena at the Guaicurus Settlement, as compared with those of the other caves, all of them located on the eastern slope (Fig. 1), was also remarkable (Table I). The distinct morphological pattern of these caves seems to be among several other factors that might explain this difference in the frequencies of phlebotomines. The lie of the strata of the western slope is horizontal or presents open, soft pleats producing a relatively greater underground development than that of the eastern slope, which presents rocks with deeper pleats and more accentuated dips (CORRÊA et al. 1979; ARAÚJO et al. 1982), forming halls with larger openings to the surface, thus favouring the entry of more light, rainwater and nutrients from the external milieu. Observations with the naked eye of the small quantity of organic matter in the caves at the western slope suggest this geological formation as being one of the factors explaining their lower phlebotomine sandfly density. Corroborating this point of view is the fact that in soil samples collected at the edge and between the middle and end of the track leading to the lake (at the bottom of the Lago Azul cave), only calcareous sediments were observed by stereomicroscopic exam. On the first half of the track, where ample light penetration occurs, beyond these sediments there were also the remains of plants, legs and carcasses of arthropods and wings of insects. In one of these samples three $3^{\text {rd }}$ instar larvae of $L$.
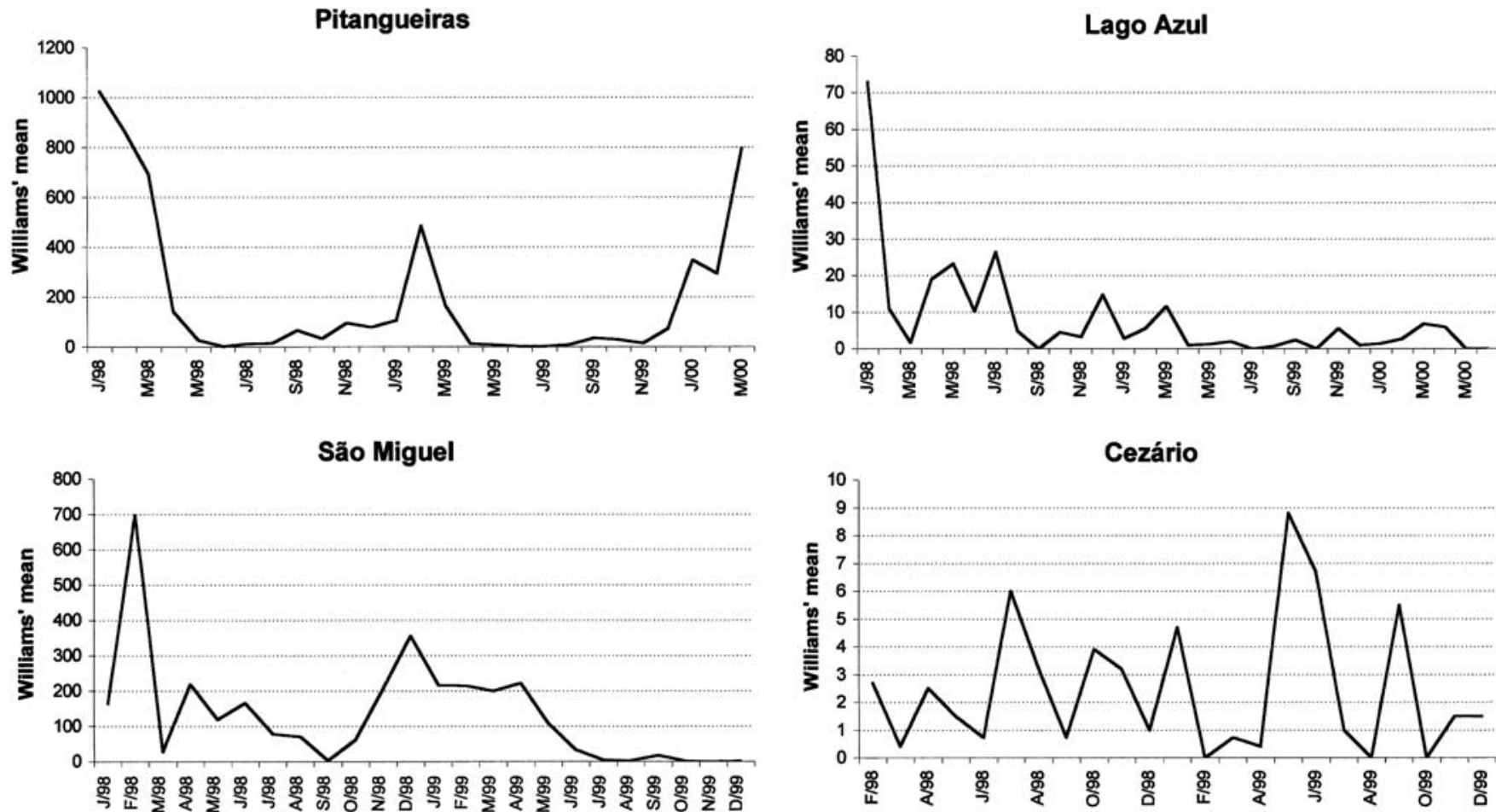

Fig. 2. Monthly distribution of Lutzomyia almerioi captured with automatic light traps in four caves of the Serra da Bodoquena. 

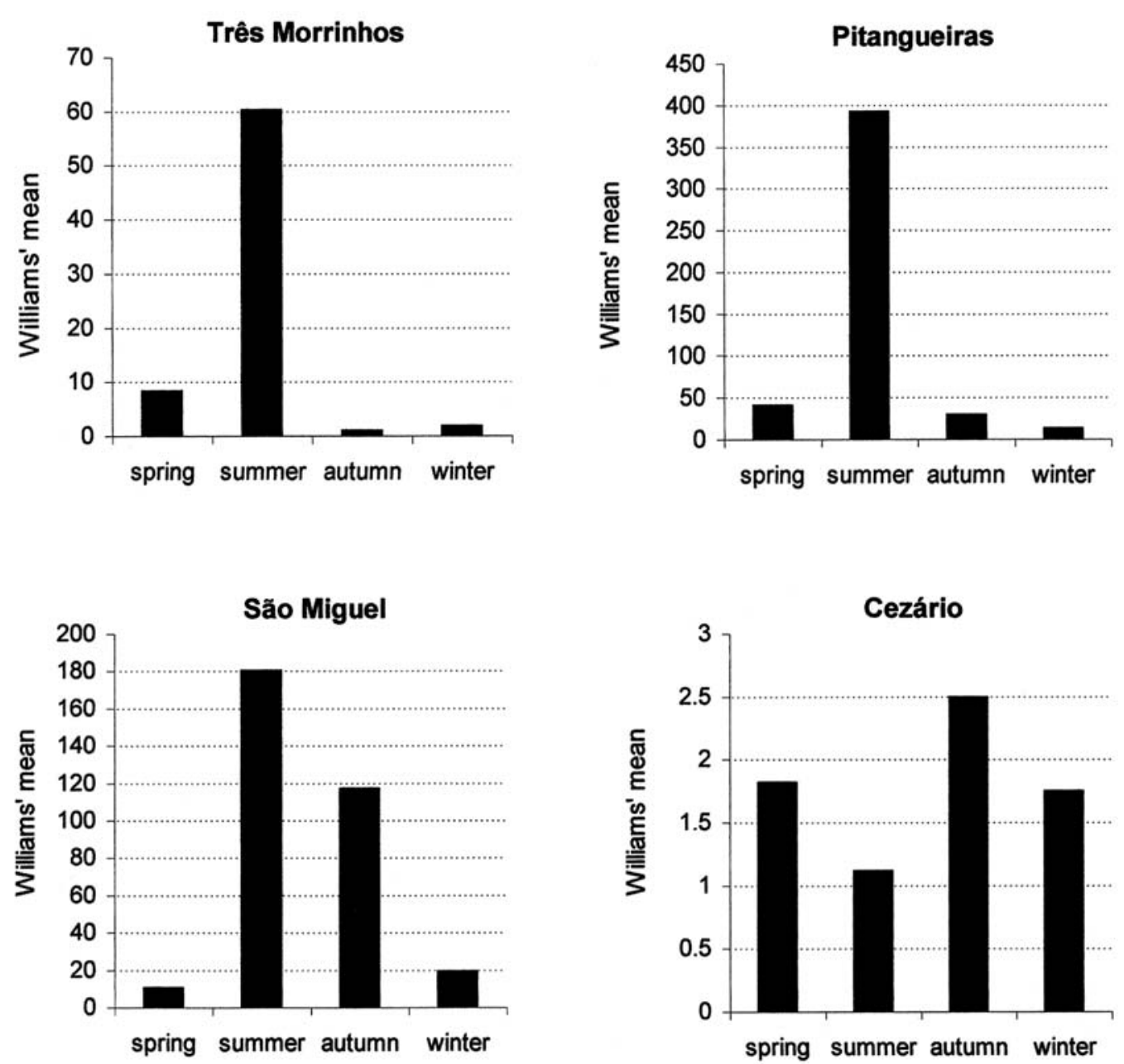

Fig. 3. Seasonal distribution of L. almerioi in caves where it was more abundant in each area.

almerioi were found.

Differently from $D$. disneyi, a species associated with caves in Central America and whose immature forms live in bat guano and have shown the highest prevalence associated with the smallest cave (WiLLiams 1976), the predominant species at the Serra da Bodoquena, L. almerioi, had its highest values at the eastern slope associated with the ample caves Pitangueiras and São Miguel, and the lowest in Lago Azul, also an ample cave. So the density, beyond being associated with the size of the caves, seems also to be associated with disturbances caused by human activity in their internal and external environments, since the Lago Azul (with low density) and $\mathrm{N}$. Sra. Aparecida (with intermediary density) caves (Table I) are close to one another and are of similar size; however, the former receives daily visits from a large number of tourists and the second is closed to the public. Perhaps both size and human activity together explain the different density of L. almerioi in the Três Morrinhos and C.C.I. caves, since they are close to each other, and the smaller frequency in the latter may be attributed to its small size and the presence of garbage due to its localization in an urban area. Even in the two caves where the species with the highest densities occurred, Pitangueiras and São Miguel, it was possible to detect the interference of human activity with the frequency of L. almerioi, during 1998/ 1999 , by analysing the seasonal variations and proportion of females (Table III). So the high number of phlebotomines in summer 1998 (1079.8 specimens per capture), 91\% being females, seems to have affected the dynamics of the L. almerioi population in the following periods much more in the Pitangueiras cave than in the São Miguel cave, that in this same season 260.3 specimens per capture, with only $36 \%$ of females were recorded. On the other hand, the frequency of $L$. almerioi in both caves, in the spring of 1999, was reduced in comparison to that of 1998, but in São Miguel the reduction was much greater than in Pitangueiras (Table III) and this, probably, was due to the modifications made in São Miguel internally and externally, for tourist purposes, during 1999, especially in the second semester.

Among several other factors that may influence the density of phlebotomines, though not measured, it was perceived the temperature in the Pitangueiras cave a little colder than in São Miguel and there was considerable circulation of 


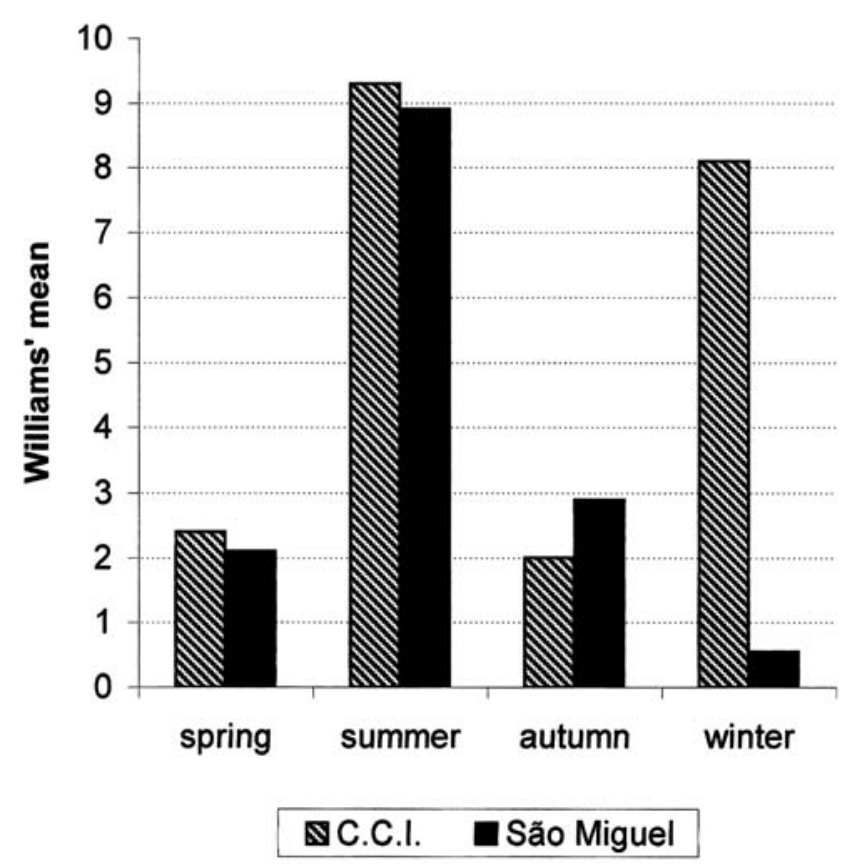

Fig. 4. Seasonal distribution of $M$. oliveirai in two caves where it was more abundant.

fresh air caused by a skylight in the ceiling of its principal hall, as well as by the three other lateral fissures that permit the entrance of vegetal debris, soil and rain water, which when deposited on the ground, whether under the rocks or inside the abundant cracks and holes in the rock walls, would favour phlebotomine breeding. In addition, there were many bats, which may provide food for the females resting in the cracks and holes, and their relatively dry dejections mixed with earth as food for the larvae, as observed for Spelaeophlebotomus gigas (Parrot \& Schwetz, 1937) in a cave with $900 \mathrm{~m}$ of galleries in Congo (Brazzaville), Central Africa. In this same cave, the immature stages of Spelaeomyia mirabilis (Parrot \& Wanson, 1939) undergo development in bat guano-earth, highly mobile and rich in organic substances, in deep, dark zones (VATTIERBERNARD 1971). This mixture was little observed in the visible part of Pitangueiras cave. On the other hand, in São Miguel with two ample entrances, it was not possible to perceive the circulation of fresh air even where there are many cracks and holes in its walls as in Pitangueiras.

Despite the perception of some factors which might affect the presence of phlebotomines in the caves, no measurements of them were taken. Thus, studies to evaluate parameters such as light penetration, temperature, humidity, winds, flow and percolation of water, presence of vertebrates and invertebrates and organic and mineral material, as well as disturbances caused by human populations that may influence the establishment of colonies of phlebotomines or make the environment favourable as resting places for the species that breed in the external milieu, need still to be undertaken.

A remarkable predominance of females of $L$. almerioi may be seen in some caves while in the others the male/female ratio is either close to $1: 1$ or the males are present in greater frequency (Table II). Possibly, the breeding, in the laboratory, of this species from the Pitangueiras and N. Sra. Aparecida caves - that accounted, respectively, for the $91 \%$ and $80 \%$ female proportion of the total population and those from the other caves - may throw light on the frequencies mentioned, since in this study it was not possible to detect any factor that might explain these results. The constant high proportion of females throughout the seasons in the Pitangueiras cave whereas in San Miguel the frequency of this sex was close to that of the males (Table III) seems to preclude obligatory hibernation as an explanation such as that given by RoUBAUD (1933) apud VANDEL (1964) for the numerous exclusively female population of Culex pipiens pipiens found in the entrance of some European caves during the winter (LERUTH 1939; TOLLET 1959 apud VANDEL 1964) where the humidity and the temperature offered favourable conditions for the transformation of the bodies of the females necessary to their reproduction.

As for the seasonal distribution of the two denser species, no single pattern was seen. The highest peak of L. almerioi in Pitangueiras, Três Morrinhos and São Miguel was observed in the summer, but in this last cave a high frequency was also observed during the autumn (Figs. 2, 3). The high frequencies of the species throughout the autumn in São Miguel can probably be explained by its localization in forested savannah, which helps to maintain the level of humidity around and within the cave at the beginning of the dry season, whereas Três Morrinhos cave, situated in pasture land, and the Pitangueiras cave, separated from the pasture only by a narrow belt of forest, are therefore, more susceptive to the effects of the low rainfall usual during this season and the winter. On the other hand, in the Lago Azul and Cezário caves, with reduced frequencies, the variation seemed to occur by chance (Figs. 2, 3).

For M. oliveirai (Fig. 4), in São Miguel the highest peak occurred in the summer. The autumn frequency was even higher than that in the other two seasons, while in C.C.I. there were two peaks, one in summer and the other in winter. The pattern of distribution and the determining factors for the frequencies in the São Miguel cave seems to be the same as those for $L$. almerioi, but in C.C.I., also situated in seasonal semideciduous submountainous forest, although less humid than that surrounding São Miguel, other factors may be required to explain this seasonal variation, perhaps associated with the population dynamics of the vertebrates which in their turn may depend on the human population, since this grotto is located in an urban environment, from which the females of $M$. oliveirai take their food.

The aspiration rendered poor results, since only 12 specimens were captured during 24 hours. The phlebotomines aspirated by cave were: C.C.I. - E. corumbaensis (1 female), $L$. almerioi (2 males, 1 female), M. oliveirai (2 males); São Miguel - L. almerioi (1 male, 3 females), M. oliveirai (1 male); Cezário L. almerioi (1 male). In Pitangueiras and Lago Azul, no sandflies 
Table IV. Number of phlebotomine specimens captured with modified automatic light traps during nocturnal period, by species, hours of exposition, caves and dissected females for observation of the natural infection by flagellates.

\begin{tabular}{|c|c|c|c|c|c|c|c|c|c|c|c|c|}
\hline \multirow[b]{2}{*}{ Species } & \multicolumn{2}{|c|}{$\begin{array}{c}\text { Pitangueiras } \\
24\end{array}$} & \multicolumn{2}{|c|}{$\begin{array}{c}\text { Lago Azul } \\
26\end{array}$} & \multicolumn{2}{|c|}{$\begin{array}{c}\text { São Miguel } \\
15\end{array}$} & \multicolumn{2}{|c|}{$\begin{array}{c}\text { N. Sra. } \\
\text { Aparecida } \\
24\end{array}$} & \multicolumn{2}{|c|}{$\begin{array}{c}\text { Cezário } \\
9\end{array}$} & \multicolumn{2}{|r|}{$\begin{array}{c}\text { Total } \\
98\end{array}$} \\
\hline & $\mathrm{m}$ & $\mathrm{f}$ & $\mathrm{m}$ & $\mathrm{f}$ & $\mathrm{m}$ & $\mathrm{f}$ & $\mathrm{m}$ & $\mathrm{f}$ & $\mathrm{m}$ & $\mathrm{f}$ & $\mathbf{m}$ & f \\
\hline B. cunhai & - & - & - & - & - & - & - & - & 1 & - & 1 & - \\
\hline E. corumbaensis & - & 2 & - & - & - & - & 1 & $9(9)$ & - & - & 1 & $11(9)$ \\
\hline L. almerioi & 7 & $88(10)$ & - & $8(8)$ & 10 & $28(26)$ & 24 & $180(142)$ & - & - & 41 & $304(186)$ \\
\hline M. oliveirai & - & - & - & - & - & $1(1)$ & - & - & - & - & - & $1(1)$ \\
\hline M. peresi & - & - & - & - & - & $3(3)$ & - & - & - & - & - & $3(3)$ \\
\hline M. quinquefer & 2 & - & - & - & - & - & - & - & - & - & 2 & - \\
\hline N. whitmani & - & - & - & - & - & - & - & 1 & - & - & - & 1 \\
\hline P. shannoni & 1 & 3 & - & - & - & - & 1 & - & - & - & 2 & 3 \\
\hline S. sordellii & - & - & - & - & - & - & 2 & 1 & - & - & 2 & 1 \\
\hline Total & 10 & $93(10)$ & - & $8(8)$ & 10 & $32(30)$ & 28 & $191(151)$ & 1 & - & 49 & 324 (199) \\
\hline
\end{tabular}

The numbers between brackets are of the dissected females for observation of natural infection by flagellates.

were aspirated. Four females of $L$. almerioi and one of $L$. corumbaensis were dissected in the search for natural infection by flagellates, with negative results.

During the nocturnal captures, using modified automatic light traps, the females from which would be dissected for investigation of natural infection by flagellates, 373 phlebotomines were captured, $86.9 \%$ of them females $(93.8 \%$ of which, L. almerioi). Among the caves sampled, N. Sra. Aparecida rendered $58.7 \%$ of the specimens and $75.9 \%$ of those dissected. Although $61.4 \%$ of the females captured were dissected, no positive specimens resulted (Table IV).

The small number of specimens dissected, 204, possibly explain the negative results, since the natural infection rates obtained in endemic areas for visceral and cutaneous leishmaniases in Mato Grosso do Sul State were found to be close to $0.39 \%$ (SANTOS et al. 1998) and $0.15 \%$ (GALATI et al. 1996), respectively. Consequently, based on these rates, at least 256 females would have to be dissected in order to detect the agent of visceral leishmaniasis, or 667 females in the case of cutaneous leishmaniasis, should transmission of these diseases be occurring in the caves. Further, though about 1,090 females of $L$. almerioi captured with human bait in the forest in front of the entrance of Pitangueiras cave were dissected, only one was found to be infected by flagellates in its middle gut (GALATI et al. 1999).

The diurnal captures in dark area of the Gaúcho cave produced only one male and one female of $L$. almerioi and one female of $M$. peresi. In the Pitangueiras cave also only these two species were captured during a total of 74 hours, two being females of $M$. peresi and the remainder being 195 males and 2,257 females of L. almerioi. So, once more, the females of L. almerioi predominated absolutely over the males. This species was also captured with no statistically different (MannWhitney's test) density for either sex in the twilight area at the entrance to the cave or in the dark area (Table V).

L. almerioi, with its daylight activity both in twilight and dark zones together with its high density and anthropophily (GALATI et al. 1999), may be identified as the most annoying sandfly for visitors as they circulate in the caves, mainly during the diurnal period and especially if they are wearing dark clothes, since it has been demonstrated in an experiment with white and black Shannon traps, that this latter colour proved to be seven times more attractive than the former (GALATI et al.2001).

The standardised index of abundance of species (Table VI), for the sixteen species obtained by the captures carried out in the eight caves in the same period, gives the highest value very close to 1.0 for $L$. almerioi, the six with highest values also including: E. corumbaensis, M. oliveirai, $S$. sordellii, $N$. whitmani and $L$. longipalpis. Of these six species, only $N$. whitmani is not recorded as being present in caves. On the other hand it was the most abundant species in forested areas of the Serra do Maracaju, in Mato Grosso do Sul State, in both automatic light and Shannon traps (GALATI et al. 1996) and the most frequent on the Chapada dos Guimarães, Mato Grosso State, in Shannon traps (BIANCARDI \& CASTELLÓN 2000).

Margalef's Diversity Index (Table VII) gives Lago Azul and N. Sra. Aparecida the highest and the lowest values, respectively, being nil in the cavities of Jardim county.

Table V. Number of specimens, by sex, of Lutzomyia almerioi captured in four collections in Pitangueiras cave, during diurnal period, totalling 22 hours of exposition, according to the cave zones and statistical significance.

\begin{tabular}{lccc}
\hline Zone & male & female & Total \\
\hline Dark & 75 & 398 & 473 \\
Twilight & 52 & 567 & 619 \\
\hline Total & $\mathbf{1 2 7}$ & $\mathbf{9 6 5}$ & $\mathbf{1 0 9 2}$ \\
\hline
\end{tabular}


Table VI. Standardised Abundance Index (SAI) for the plebotomines captured in the caves: CCI, Três Morrinhos, Gaúcho, Cezário, Patrimônio, Pitangueiras, São Miguel and Lago Azul, in the period from August 1998 to December 1999.

\begin{tabular}{lcc}
\hline Species & SAI & Position \\
\hline Lutzomyia almerioi & 0.99 & $1^{\text {st }}$ \\
Evandromyia corumbaensis & 0.79 & $2^{\text {nd }}$ \\
Martinsmyia oliveirai & 0.74 & $3^{\text {rd }}$ \\
Sciopemyia sordellii & 0.65 & $4^{\text {th }}$ \\
Nyssomyia whitmani & 0.62 & $5^{\text {th }}$ \\
Lutzomyia longipalpis & 0.61 & $6^{\text {th }}$ \\
Brumptomyia cunhai & 0.34 & $7^{\text {th }}$ \\
Micropygomyia peresi & 0.31 & $8^{\text {th }}$ \\
Psathyromyia shannoni & 0.23 & $9^{\text {th }}$ \\
Micropygomyia quinquefer & 0.21 & $10^{\text {th }}$ \\
Brumptomyia avellari & 0.15 & $11^{\text {th }}$ \\
Brumptomyia brumpti & 0.13 & $12^{\text {th }}$ \\
Psathyromyia punctigeniculata & 0.13 & $12^{\text {th }}$ \\
Pintomyia kuscheli & 0.05 & $13^{\text {th }}$ \\
Micropygomyia acanthopharynx & 0.05 & $13^{\text {th }}$ \\
Brumptomyia galindoi & 0.01 & $14^{\text {th }}$ \\
\hline
\end{tabular}

Although low densities of individuals may also occur with species whose life cycles are dependent on caves, the low frequencies of the majority of the species and their capture also in forests (paper in preparation) suggest that they may be using the caves just as shelters (resting places). The light traps installed to attract the phlebotomines in the entrances to caves, certainly contributed to the presence of many species that breed in forest soil among roots, fallen leaves, in animal burrows or under rocks and stones, very frequent in the region, such as the species of Brumptomyia and some of Psathyromyia, especially of the subgenus Forattiniella, to which $P$. campograndensis belongs, that usually live in armadillo burrows and Nyssomyia, Pintomyia and some Psathyromyia which are also closely associated with the forests (CIPA Group 1999). Thus, comparing the two caves with high density and a long period of capture, Pitangueiras and São Miguel (Table I), the surrounding external environment of this latter, a relatively well preserved forested savannah, possibly contributed with a higher number of accidental trogloxene species than Pitangueiras, surrounding vegetation of which, though having similar characteristics to that of the former, is preserved only in a narrow belt, thus with a more greatly reduced number of ecotopes that may serve as breeding places for the species. These facts and the $62.3 \%$ higher density in Pitangueiras than in São Miguel may explain the higher diversity index in this latter (Table VII). In the cave with the highest density, Estreito da Serra (Table I), though situated in an extensive area of primitive seasonal semideciduous submountainous vegetation, the few captures made may have led to the underestimation of the index. For the caves with median densities,
Três Morrinhos, C.C.I. and N. Sra. Aparecida, the differences found between the first two and the last may have been influenced by the period of sampling. For the caves with low densities, Lago Azul, Cezário, Patrimônio and Gaúcho, the highest index for the first may be explained by the ample entrance area that may be more attractive for several accidental trogloxene species, since its surrounding dense and relatively well preserved vegetation may create favourable conditions for the breeding of these species and also because of the longer period of capture than that of the other caves. The difference between Gaúcho and Cezário, this latter with the higher density and the greater diversity, was perhaps affected by the proximity of the anthropic environment, since it is situated in an area of seasonal deciduous submountainous vegetation, close to a peridomicile containing domestic animal shelters that may serve as breeding sites for phlebotomines, mainly $L$. longipalpis, the most important vector of visceral leishmaniasis in Latin America. Noteworthy in this cave was the capture of $P$. kuscheli, which represents the first recording of this species described for a Bolivian subandean area (LE PONT et al. 1998), in Brazil.

Though the isolation of immature sandfly forms from natural substrates is rare (FORATTINI 1973), three $3^{\text {rd }}$ instar larvae were found in a soil sample collected in Lago Azul cave in July 1999. The soil was obtained with the help of the branch of a bush, from a cavity (about $80 \mathrm{~cm}$ in depth) under the rock wall of the cave, where no light could penetrate. This cavity was situated at the edge of the track that leads to the lake, half way down the steps. In the laboratory, the larvae were maintained in the moist soil in a small flask containing filter paper in its bottom. In the next day they were found dead under the paper. The identification of the larvae as belonging to L. almerioi was possible after the breeding of this species in the laboratory. The larvae present a dark brown head and the thorax and abdomen completely lacking pigmentation as constantly happens with animals living in caves (VANDEL 1964).

Table VII. Diversity Index of Margalef (D) in the caves sampled of the Serra da Bodoquena.

\begin{tabular}{lc}
\hline Cave & D \\
\hline Lago Azul & 1.73 \\
Cezário & 1.52 \\
São Miguel & 1.46 \\
Patrimônio & 1.39 \\
Gaúcho & 1.25 \\
Três Morrinhos & 1.23 \\
C.C.I. & 1.18 \\
Pitangueiras & 1.05 \\
Estreito da Serra & 0.97 \\
N. Sra. Aparecida & 0.83 \\
Buraco das Abelhas & 0 \\
Buraco da Sucuri & 0 \\
\hline
\end{tabular}


From the observations, it is possible to conclude that $L$. almerioi is breeding in caves of Serra da Bodoquena; its females may be practising haematophagy inside and outside the caves and that carbohydrate energy is obtained by both sexes from sources in the external environment; so the species may be identified as troglophile. M. oliveirai, E. corumbaensis, $S$. sordellii, $M$. peresi and $L$. longipalpis may also be identified as troglophile, in relation to some of the caves. The other species may be identified as trogloxenes, using the caves just as shelters, including $N$. whitmani, a vector of cutaneous leishmaniasis in many forested and peridomiciliary Brazilian areas (CuBA-CuBa et al. 1985; Queiroz et al. 1994; Galati et al. 1996, Luz et al. 2000) and those of the genera Brumptomyia, Pintomyia and Psathyromyia.

Lutzomyia almerioi was the most abundant species in the caves sampled in the Bodoquena and Bonito counties, having its highest densities on the eastern slope. However, it was not found in the cavities situated further to the south on the western slope. Its greatest frequencies were observed in summer, but in some caves peaks were observed in autumn and winter. It presents both diurnal and nocturnal activities, bites humans avidly and was captured both in the entrances and dark areas of the caves, and may hence be considered the most bothersome phlebotomine to persons who frequent the caves, mainly those at the eastern slope, where the majority of tourist activities are centred. Though no infected females from captures undertaken in caves were observed, the possibility of their participation in the transmission of flagellates among mammals calls for further investigation, since females captured in the forest close to the Pitangueiras cave were naturally infected, although the parasite has not yet been identified.

Ackowledgements. Thanks are due to FAPESP (Process no. 97/ 06438-3) and COMTUR - Bonito for the financial support given for this project and to IBAMA/ DIREC/ CECAV for the licences to undertake research in the caves named - no. 007/98 Bodoquena county; no. 008/98 and 003/00 (Pitangueiras, São Miguel, Lago Azul and N. Sra. Aparecida); no. 010/98 (Guaicurus Settlement); IPHAN/14 ${ }^{\mathrm{a} C R} / 11$ no. 025/98 (Lago Azul cave). We are grateful to various of the inhabitants of the Serra da Bodoquena: Mrs. Adélia Gonçalves de Souza and Messrs. Sérgio Ferreira Gonzales, José Barbosa de Araújo and Ceciliano Pereira for their collaboration in the captures and Dr. João Carlos Meirelles, owner of the Pitangueiras farm, and Mr. João Alberto Baptistella, owner of the São Bento farm, for having provided us with the necessary facilities during field research.

\section{REFERENCES}

Araújo, H. J. T.; A. Santos Neto; C. A. H. Trindade; J. C. A. Pinto; R. M. G. Montalvão; T. D. C. Dourado; R. C. B. Palmeira \& C. C. G. Tassinari. 1982. Folha SF-21- Campo Grande, 1- Geologia. Rio de Janeiro, Projeto RADAMBRASIL, v. 28: 9-124.

Biancardi, C. M. A. B. \& E. G. Castellón. 2000. Flebotomíneos (Diptera: Psychodidae) no Estado de Mato Grosso, município de Chapada dos Guimarães, Brasil. Acta Amazonica 30(1): 115-128.

Boggiani, P. C. 2001. Ciência, meio ambiente e turismo em Bonito: a combinação que deu certo? p. 151-165. In: A. BANDUCCI JÚNIOR \& E. C. Moretti (organizadores). Qual Paraiso? Turismo e ambiente em Bonito e no Pantanal. São Paulo, Editora da UFMS e

\section{CHRONOS}

Boggiani, P. C. \& A. M. Coimbra. 1995. Quaternary limestone of the pantanal area, Brazil. Anais da Academia Brasileira de Ciências 67: 343-349.

Cipa Group, 1999. Computer-aided Identification of Phlebotomine Sandflies of America. http://cipa.snv.jussieu.fr

Colmenares, M.; M. Portús; J. Botet; C. Dobaño; M. Gállego; M. WolfF \& G. Seguí. 1995. Identification of blood meals of Phlebotomus perniciosus (Diptera: Psychodidae) in Spain by a Competitive Enzyme Linked Immunosorbent Assay Biotin/Avidin Method. Journal of Medical Entomology 32(3): 229-33.

Corrêa, J. A.; F. C. Correia Filho; G. Scislewski; C. Neto; L. A. Cavallon; N. L. S. Cerqueira \& V. L. Nogueira. 1979. Geologia das regiões centro e oeste de Mato Grosso do Sul. Projeto Bodoquena. Série Geologia DNPM, v. 6: 1-111.

Cuba-Cuba, C. A.; M. A. Miles; A. Vexenat; D. C. Barker; D. Mcmahon Pratt; J. Butcher; A. C. Barreto \&. P. H. Marsden. 1985. A focus of mucocutaneous leishmaniasis in Três Braços, Bahia, Brazil: Characterisation and identification of Leishmania stocks isolated from man and dogs. Transactions of the Royal Society of the Tropical Medicine and Hygiene 79(4): 500-507.

Dessen, B. E. M.; V. R. Eston; M. S. Silva; M. T. Temperini-Beck \& E. Trajano. 1980. Levantamento preliminar da fauna de cavernas de algumas regiões do Brasil. Ciência e Cultura 32: 714-725.

DNM - Departamento Nacional de Meteorologia 1992. Normas Climatológicas - Brasil.

Falqueto, A.; G. Grimaldi-Júnior; P. A. Sessa; J. B. M. Varejão \& L. M. Deane. 1985. Lutzomyia gasparviannai Martins, Godoy \& Silva, 1962, probable vector of Leishmania mexicana ssp. in Viana municipality, Espírito Santo State, Brazil. Memórias do Instituto Oswaldo Cruz 80 (4): 497.

Forattini, O. P. 1973. Entomologia Médica. Phlebotominae. Leishmanioses. Bartonelose. $4^{\circ}$ v. São Paulo, Edgard Blücher Ltda, 658p

Furtado, P. P.; J. G. Guimarães \& B. C. Fonzar. 1982. Folha SF-21- Campo Grande, 4 - Vegetação. Rio de Janeiro, Projeto RADAMBRASIL, v.28: $281-336$.

Galati, E. A. B. 1995. Phylogenetic systematics of Phlebotominae (Diptera, Psychodidae) with emphasis on American groups. Boletín de la Dirección de Malariología y Saneamiento Ambiental 35 (Supl. 1): 133-142.

Galati, E. A. B \& V. L. B. Nunes. 1999. Descrição de Lutzomyia (Lutzomyia) almerioi, sp. n. (Diptera, Psychodidae, Phlebotominae) do Mato Grosso do Sul, Brasil. Revista Brasileira de Entomologia 43(3/4): 277-285.

Galati, E. A. B.; V. L. B. Nunes; M. E. C. Dorval; P. C. Boggiani, G.; J. J. Shaw; Cristaldo; H. C. Rocha; R. M. G. Andrade, C. Casanova \& G. NAUfEL. 1999. Ecological aspects of the phlebotomine fauna from Serra da Bodoquena, Mato Grosso do Sul State, Brazil. $3^{\text {rd }}$ International Symposium on Phlebotomine Sandflies. Montpellier, Programme \& Abstracts, p. 36.

Galati, E. A. B.; V. L. B. Nunes; M. E. C. Dorval; G. Cristaldo; H. C. Rocha; R. M. GonÇalves-Andrade \& G. Naufel. 2001. Attractiveness of black Shannon trap for phlebotomines. Memórias do Instituto Oswaldo Cruz 96(5): 641-647.

Galati, E. A. B.; V. L. B. Nunes; M. E. C. Dorval; E. T. Oshiro; G. Cristaldo; M. A. Espindola; H. C. Rocha \& N. B. Garcia. 1996. Estudos dos flebotomíneos (Diptera, Psychodidae) em área de leishmaniose tegumentar, no Estado de Mato Grosso do Sul, Brasil. Revista de Saúde Pública 30(2): 115-128.

Galati, E. A. B.; V. L. B. Nunes; F. A. Rego-Jr; E. T. Oshiro \& M. Rodrigues. 1997. Estudo de flebotomíneos (Diptera, Psychodidae) em foco de leishmaniose visceral no Estado de Mato Grosso do Sul, Brasil. Revista de Saúde Pública 31(4): 378-90.

Gnaspini-Netto P.; E. Trajano \& L. E. Sánchez. 1994. Província espelológica da Serra da Bodoquena, MS: exploração, topografia e biologia. EspeloTema 17: 19-44.

HadDow, A. J. 1960. Studies on the biting-habits and medical importance of East African mosquitos in the genus Aedes. I. Subgenera Aedimorphus, Banksinella and Nunnius. Bulletin of Entomological 
Research 50: 759-779.

Kholer, H. C.; Auler, A. \& M. B. Cattanio.1998. The Subtropical Karst of Bonito, Western Brazil; p. 257-267. In: Y. Daoxian \& L. Zainua. 1998. Global Karst Correlation. Science Press and VSP BV.

Le Pont, F.; E. Martinez; J. M. Torrez-Espejo \& J. P. Dujardin. 1998. Phlébotome de Bolivie: description de cinq nouvelles espèces de Lutzomyia de la région subandine (Diptera, Psychodidae). Bulletin de la Société Entomologique de France 103(2): 159-173.

Lino, C. F.; P. C. Boggiani; J. Cortesão, N. M. Godoy \& I. Karmann. 1984. Projeto Grutas de Bonito. Diretrizes para um plano de manejo turístico. Relatório inédito, SPHAN/MS-TUR. 212 p, mapas.

Lugo, J.; T. Aldecoa; E. Miqueli \& J. L. Pelegrino. 1991. Actividad de picada diurna y densidad estacional de Lutzomyia (C.) orestes (Diptera: Psychodidae). Revista Cubana de Medicina Tropical 43(2): 9295.

Luz, E.; N. Membrive; E. A. Castro; F. Dereure; J. Pratlong; J. A. Dedet; A. Pandey \& V. Thomaz-Soccol. 2000. Lutzomyia whitmani (Diptera: Psychodidae) as vector of Leishmania $(V$.) braziliensis in Paraná state, southern Brazil. Annals of Tropical Medicine and Parasitology 94(6): 623-631.

Morrison, A. C.; C. Ferro \& R. Tesh. 1993. Host preference of sand fly Lutzomyia longipalpis at an endemic focus of american visceral leishmaniasis in Colombia. American Journal of Tropical Medicine and Hygiene 49(1): 68-75.

Natal, D.; D. Marucci; I. M. Reis \& E. A. B. Galati. 1991. Modificação da armadilha CDC com testes para coletas de flebotomíneos (Diptera). Revista Brasileira de Entomologia 35(4): 697-700.

Poulson, T. L. \& W. B. White. 1969. The cave environment. Limestone caves provide unique natural laboratories for studying biological and geological processes. Science 165, N. 3897: 971-981.

Queiroz, R. G.; I. A. B. Vasconcelos; A. W. Vasconcelos; F. A. C. Pessoa; R. N. SouzA \& J. R. DAVID. 1994. Cutaneous leishmaniasis in Ceara state in northeastern Brazil: incrimination of Lutzomyia whitmani (Diptera: Psychodidae) as a vector of Leishmania braziliensis in
Baturite municipality. American Journal of Tropical Medicine and Hygiene 50(6): 693-698, 1994.

Roberts, D. R. \& B. P. Hsi. 1979. An index of species abundance for use with mosquito surveillance data. Environmental Entomology 8(6): 1007-1013.

Sallum Filho, W. 1996. Gruta Pitangueiras. In: S. Ayub; W. Sallum Filho; N. B. Ferreira; A. E. S. Abreu; A. L. G. P. Teixeira \& T. S. H. EleUtÉRIO.1996. Caracterização geo-espeleológica preliminar das cavernas da porção central da Serra da Bodoquena, na região de Bonito, MS. Relatório elaborado pelo Grupo Espeleológico da Universidade de São Paulo - GGEO, XI + 51 p.

Santos, S. O; J. Arias; A. A. Ribeiro; M. P. Hoffmann; R. A. Freitas \& M. A. F. MalaCCO. 1998. Incrimination of Lutzomyia cruzi as a vector of American visceral leishmaniasis. Medical Veterinary Entomology. 12: $315-7$.

Service, M. W. 1993. Mosquito Ecology: Field Sampling Methods. London, Chapman \& Hall, 988p.

Siegel, S. 1975. Estatística Não Paramétrica para Ciências do Comportamento. São Paulo, McGraw Hill, 350 p.

Vandel, A. 1964. Biospeologie. La biologie des animaux cavernicoles. Paris, Gauthier-Villars, 619p.

Vattier-Bernard, G. 1971. Notes sur la biologie de deux espèces de phébotomes cavernicoles africains. Bulletin d' Ecologie 2(4): 293301 .

Veloso, H. P; A. L. R. Rangel Filho \& J. C. A. Lima. 1991. Classificação da Vegetação Brasileira, Adaptada a um Sistema Universal. Rio de Janeiro, IBGE, 124 p.

Williams, P. 1976. The phlebotomine sandflies (Diptera, Psychodidae) of caves in Belize, Central America. Bulletin of Entomological Research 65: 601-614.

Young, D. G. \& M. A. Duncan. 1994. Guide to the identification and geographic distribution of Lutzomyia sand flies in Mexico, the West Indies, Central and South America (Diptera: Psychodidae). Memoirs of the American Entomological Institute 54: 1-881. 